\title{
THE OUALITY COMPARISON OF PARTICLEBOARDS PRODUCED FROM HEARTWOOD AND SAPWOOD OF EUROPEAN LARCH
}

\author{
Selahattin Bardak ${ }^{1, \$}$, Gökay Nemli², Timuçin Bardak
}

\begin{abstract}
In this paper, the impacts of heartwood and sapwood usage on the physical, mechanical, and surface properties and formaldehyde emission of particleboard are investigated. European Larch (Larix decidua) trees are chosen as a raw material. The logs are divided into three segments: sapwood, heartwood and total wood. The highest amounts of cellulose $(51,54 \%)$, and hemicelluloses $(22,24 \%)$ in the sapwood, followed by total wood, and the heartwood, respectively. However, the highest amount of lignin $(30,54 \%)$ was found in the heartwood. The highest extractives values are obtained from heartwood, followed by total wood, and the sapwood, respectively. While the lowest $\mathrm{pH}$ value $(3,03)$ is found in heartwood, the sapwood samples provide the highest values $(4,95)$. The highest ash $(0,49 \%)$ content and amount of condensed tannin $(13,89 \%)$ are extracted from heartwood, followed by total wood, and sapwood, respectively. The test panels manufactured from sapwood have the smoothest surface $\left(7,49 \mu \mathrm{m}\left(\mathrm{R}_{\mathrm{r}}\right) 48,86 \mu \mathrm{m}\left(\mathrm{R}_{\mathrm{v}}\right)\right.$, and 35,12 $\left.\mu \mathrm{m}\left(\mathrm{R}_{\mathrm{z}}\right)\right)$ and the lowest contact angles $\left(67,8^{\circ}\right)$, while the roughest surface $\left(14,20 \mu \mathrm{m}\left(\mathrm{R}_{\mathrm{a}}\right) 68,05 \mu \mathrm{m}\left(\mathrm{R}_{\mathrm{v}}\right)\right.$, and 50,02 $\left.\mu \mathrm{m}\left(\mathrm{R}_{\mathrm{z}}\right)\right)$ and highest contact angle $\left(96,9^{\circ}\right)$ are obtained from the panels of heartwood. The thickness swelling $(19,88 \%)$ and formaldehyde emission $(7,28 \%)$ values of the panels manufactured from heartwood are significantly lower than the panels manufactured from the total wood and sapwood. The highest modulus of rupture (MOR), modulus of elasticity (MOE), and internal bond (IB) values are observed on sapwood, respectively, 15,60 MPa (MOR), $2201 \mathrm{MPa}$ (MOE), and 0,523 MPa (IB). These mechanical strength values (MOR, MOE, and IB) are followed by total wood, and the heartwood, respectively. Surface smoothness and wettability of the particleboards manufactured from sapwood are better than those of total wood and heartwood.
\end{abstract}

Keywords: Contact angle, formaldehyde emission, Larix decidua, mechanical properties, physical properties, roughness.

\section{INTRODUCTION}

Particleboard is a very popular engineered wood based panel product manufactured from wood particles and synthetic resins or other suitable binders (Baharoglu et al. 2013). Another definition of particleboard is given as a wood-based panel composite consisting of varying sizes and shapes of particles from lignocellulosic materials bonded together with an adhesive under high temperature and pressure (Sari et al. 2013). The production of particleboards has positive effects on the environment due to using wood residues (Garay et al. 2009)

Particleboard is a wood-based panel composite used in the manufacturing of floor underlayment, shelving, tables, counters, wall and ceiling, stair treads, bulletin boards, home constructions, kitchen worktops, interior decoration, cabinets and furniture (Nemli and Demirel 2007).

\footnotetext{
${ }^{1}$ Department of Industrial Engineering, Faculty of Engineering and Architecture, Sinop University, Sinop, Turkey.

${ }^{2}$ Department of Forest Industry Engineering, Faculty of Forestry, Karadeniz Technical University, Trabzon, Turkey.

${ }^{3}$ Furniture and Decoration Program, Bartin Vocational School, Bartin University, Bartin, Turkey.

•Corresponding author: selahattinbardak@hotmail.com
}

Received: 04.12.2017 Accepted: 10.07.2019 
Particleboards are mostly used in three layers. Demand for particleboard has been increasing steadily in recent years. The reason for this increase may be due to the fact that the particleboard is a low cost product and can be used in many applications.

Many studies have been performed on the effects of various factors on the quality properties of particleboard. These factors are; the usages of various raw materials such as wood bark (Blanchet et al. 2000), pine cone (Ayrilmis et al. 2009), cotton (Gossypium hirsutum) stalks (Nazerian et al. 2016), canola (Brassica napus) straws (Kord et al. 2016), and needle litter (Nemli et al. 2008), different parameters of the wood such as log position (Muhcu et al. 2015), permeability of wood (Lyman 1969), anatomical and chemical properties of wood (Baharoglu et al. 2013), moisture content of raw material (Baharoglu et al. 2012), acidity of the particles (Akyuz et al. 2010), wood extractives (Foster 1967), density of wood (Maloney 1977), mature and juvenile wood (Wasniewski 1989), and raw material growth region (Bardak et al. 2017). The parameters of the particleboard production, such as dimensions of the particles (Motted 1967), residue type and tannin content (Moubarik et al. 2013), paraffin application technique (Baharoglu et al. 2014), hardener type, urea usage and conditioning period (Atar et al. 2014), solid content of the adhesive and panel density (Sari et al. 2013), decor paper properties (Bardak et al. 2011), and shelling ratio (Nemli and Ozturk 2006) are investigated.

In this study, it is aimed to understand the effect of sapwood and heartwood usage on the physical (thickness swelling) and mechanical (modulus of rupture (MOR), modulus of elasticity (MOE), and internal bond (IB)) properties, surface roughness, and formaldehyde emission of particleboard panels. Besides, how chemical properties of sapwood, heartwood, and total wood affected quality properties of particleboards are investigated.

\section{MATERIALS AND METHODS}

Ten European Larch (Larix decidua Mill.) trees were felled from a private forest in Trabzon, Black Sea region of Turkey. The age and breast height diameter of the trees were 45 years old and $30 \mathrm{~cm}$, respectively. The bark of logs was removed before chipping. The logs were divided into three segments: sapwood (diameter: $19 \mathrm{~cm}$ ), heartwood (diameter: $11 \mathrm{~cm}$ ), total wood (diameter: $30 \mathrm{~cm}$ ): Segments were chipped using a ring type flaker. The chips were then reduced into smaller particles using a hammer mill. The particles were dried to 3\% moisture content in a dryer. The dried particles were classified into two sizes using a 3,0-1,5-0,8 mm openings vibrating screen for the core and face layers. Based on oven dry weight of particle weight, $9 \%$ and $11 \%$ urea formaldehyde resin was applied for core and face particles, respectively. The ratio of the face thickness to the total thickness of a panel known as the shelling ratio was 0,35 for all samples. Ammonium sulphate (concentration: $20 \%$ ) was used as a hardener during the blending process by about $1 \%$ based on the solid amount of adhesive. No wax or any other additives were used for the panel manufacture. The specifications of the use urea formaldehyde are presented in Table 1.

Table 1: The specifications of urea formaldehyde.

\begin{tabular}{|c|c|}
\hline Solid Content & $65 \%$ \\
\hline Gel Time & $94 \mathrm{~s}$ \\
\hline Viscosity & $178 \mathrm{cp}$ \\
\hline
\end{tabular}

Mats formed manually in a frame with a size of $550 \times 550 \mathrm{~mm}$ were hot pressed at a temperature of $150{ }^{\circ} \mathrm{C}$ using a pressure of 2,5 MPa for $6 \mathrm{~min}$. All panels were pressed to a nominal thickness of 12,0 $\mathrm{mm}$ and an average target density of $0,70 \mathrm{~g} / \mathrm{cm}^{3}$. A total of 9 experimental panels, 3 panels for each type of particleboard, were produced. The experimental design of the study is illustrated in Table 2. 
Table 2: The experimental design of the study.

\begin{tabular}{|c|c|}
\hline Panel Types & Wood Types \\
\hline A & Heartwood \\
\hline B & Sapwood \\
\hline C & Total wood \\
\hline
\end{tabular}

Until the panels reached equilibrium moisture content, they were kept in a conditioned room with a relative humidity of $65 \%$ and a temperature of $20^{\circ} \mathrm{C}$. Mechanical properties- MOR (the samples with dimensions of $300 \mathrm{~mm} \times 50 \mathrm{~mm} \times 12 \mathrm{~mm}$ ) and MOE (the samples with dimensions of $300 \mathrm{~mm} \times 50 \mathrm{~mm} \times 12 \mathrm{~mm}$ ) (EN 310 1993), and IB (the samples with dimensions of $50 \mathrm{~mm}$ x $50 \mathrm{~mm}$ x $12 \mathrm{~mm}$ ) (EN 319 1993)), and physical property- thickness swelling (TS) (the samples with dimensions of $50 \mathrm{~mm}$ x $50 \mathrm{~mm}$ x $12 \mathrm{~mm}$ ) (EN 317 1993) of particleboards were determined according to European standards. Thirty samples were replicated and used for physical (TS) and mechanical (MOR, MOE, and IB) tests.

Determination of the chemical properties of the woods and preparation of the test specimens were carried out according to TAPPI standard TAPPI T M-45 (1992) standard. Alcohol-benzene TAPPI T $204 \mathrm{~cm}-97$ (1997), hot and cold water (2 g air-dried sample) TAPPI T 207 om-88 (1988) and dilute alkali (1\% NaOH) solubility's (2 gair-dried sample) TAPPI T 212 om-98 (1998), lignin content (1 g air-dried sample) TAPPI T 222 om-02 (2002) and amount of ash (4-5 g air-dried sample) TAPPI T 211 (1993) were determined according to the cited standards. Holocellulose ( $5 \mathrm{~g}$ air-dried sample exposed by alcohol-benzene extraction) and cellulose contents ( $2 \mathrm{~g}$ air-dried sample exposed by alcohol-benzene extraction) were determined by chlorite and nitric acic methods (Wise and Karz 1962). The acidity was measured in an extract solution made by $3 \mathrm{~g}$ wood flour added to $100 \mathrm{ml}$ water and boiled for $30 \mathrm{~min}$ (Prasetya 1989). Amount of condensed tannins was determined according to the method developed by Tisler and friends (Tisler et al. 1986). Three samples were replicated and used for determination of chemical properties.

The samples with the dimensions of $50 \mathrm{~mm} \times 50 \mathrm{~mm} \times 12 \mathrm{~mm}$ used for surface roughness tests were sanded with a sequence of 100 and 150 grit sand papers. The samples to be used in surface roughness were conditioned in a climate chamber at $20^{\circ} \mathrm{C}$ and $65 \% \mathrm{RH}$. A Mitutoyo SJ-301 surface roughness tester, a stylus type profilometer, was employed for the surface roughness tests. Three roughness parameters characterized by ISO 4287 (1997) standard, which are average roughness (Ra), mean peak-to-valley height (Rz), and maximum peak-tovalley height (Ry), were considered to evaluate the surface characteristics of the panels. A total of 60 roughness measurements were performed, with 4 measurements for each type of particleboard of 15 samples. Two of the measurements were performed parallel to the sand marks while the other two were performed perpendicular to the sand marks.

The wetting behavior of the particleboard samples conditioned at $65 \% \mathrm{RH}$ and $20^{\circ} \mathrm{C}$ was characterized by the CA method (goniometer technique). Contact angle (CA) measurements were performed using a CAM 101 Optical Contact Angle Meter (KSV Instruments Ltd., Helsinki), equipped with a video camera. Using the sessile drop method, which is the most widely used procedure, the contact angle was determined simply by aligning tangent with the sessile drop profile at the point of contact with the solid surface. An imaging system was used to measure contact angle and droplet shape for the tested surfaces of the samples. The image of the liquid drop was captured by a video camera, and the CA was measured by the digital image analysis software. After 5-mL droplet of the distilled water was placed on the sample surface, CAs from the images were measured for $5 \mathrm{~s}$. A total of 30 contact angle measurements, two from each of 15 samples, were performed for each type of panel.

Three samples with the dimensions of $20 \mathrm{~mm}$ x $20 \mathrm{~mm}$ x $12 \mathrm{~mm}$ were randomly taken from each type of particleboard for the determination of formaldehyde emission (FE) by the perforator method based on EN 1201 (1994) standard. In this method, the free formaldehyde in the board is determined by extraction. According to the standards, free formaldehyde is fed into the distilled water from the board samples boiled in toluene and the amount of formaldehyde in the aqueous solution is determined photometrically and proportioned to the weight of the full dry board (Bardak 2014).

One-way analysis of variance, ANOVA, was conducted $(p \leq 0,05)$ to evaluate the effect of sapwood, heartwood usage on the quality properties of the panels. Significant differences between the mean values of the 
panel types were determined using Newman-Keuls's test.

\section{RESULTS AND DISCUSSION}

\section{Chemical properties}

The highest amounts of cellulose (49,12\%), hemicelluloses $(22,24 \%)$ were found in the sapwood, followed by total wood, and the heartwood, respectively. However, the highest amount of lignin amounts $(30,54 \%)$ was found in the heartwood. The average values of chemical properties of furnishes are presented in Table 3. According to the results of statistical analysis, all the chemical properties of the samples were significantly affected by the furnish type. The highest solubility values were obtained from heartwood, followed by total wood, and the sapwood, respectively. While the lowest $\mathrm{pH}$ of extract value $(3,03)$ was found in heartwood, the sapwood provided the highest $\mathrm{pH}$ of extract values $(4,95)$. The highest ash content $(0,49 \%)$, and amount of condensed tannin $(13,89 \%)$ were found in heartwood, followed by total wood, and sapwood, respectively. Generally, the heartwood contains higher amounts of extracts than sapwood (Ors and Keskin 2001, Sivrikaya 2008). In addition, holocellulose and cellulose amounts in sapwood of pinus nigra, fir and oak were higher than the one in the heartwood. However, lignin amount, cold and hot water, alcohol and $1 \% \mathrm{NaOH}$ solubilities in heartwood of pinus nigra, fir and oak were found to be higher than the one in the sapwood (Atac 2009). In the study conducted by Campbell et al. 1990, it was found that the extractive content of heartwood was significantly higher than sapwood in latifolia (3,30\% vs. 2,03\%) and murrayana and the alpha-cellulose content of sapwood was also significantly higher than that of heartwood in latifolia $(49,38 \%$ vs. $46,02 \%)$ and murrayana $(49,52 \%$ vs. $44,17 \%)$ (Campbell et al. 1990). Based on these findings, we can safely express that our results agree with the previous studies.

Table 3: Chemical properties of total wood, heartwood and sapwood.

\begin{tabular}{|c|c|c|c|}
\hline \multirow{2}{*}{ Chemical properties } & \multicolumn{3}{|c|}{ Wood types } \\
\cline { 2 - 4 } & Total wood & Heartwood & Sapwood \\
\hline pH of extract & 4,58 & 3,03 & 4,95 \\
& $(0,03)(\mathrm{a})$ & $(0,08)(\mathrm{b})$ & $(0,04)(\mathrm{c})$ \\
\hline Solubility in dilute alkali (1\% NaOH) & 15,56 & 25,51 & 12,33 \\
$(\%)$ & $(0,21)(\mathrm{a})$ & $(0,43)(\mathrm{b})$ & $(0,32)(\mathrm{c})$ \\
\hline Extractives (\%) & 5,68 & 8,73 & 5,02 \\
& $(0,14)(\mathrm{a})$ & $(0,25)(\mathrm{b})$ & $(0,16)(\mathrm{c})$ \\
\hline Solubility in cold water (\%) & 2,54 & 4,87 & 2,13 \\
& $(0,08)(\mathrm{a})$ & $(0,05)(\mathrm{b})$ & $(0,03)(\mathrm{c})$ \\
\hline Solubility in hot water (\%) & 5,45 & 7,89 & 5,02 \\
& $(0,09)(\mathrm{a})$ & $(0,15)(\mathrm{b})$ & $(0,11)(\mathrm{c})$ \\
\hline Cellulose (\%) & 49,12 & 45,02 & 51,54 \\
& $(0,17)(\mathrm{a})$ & $(0,10)(\mathrm{b})$ & $(0,06)(\mathrm{c})$ \\
\hline Hemicellulose (\%) & 19,02 & 17,59 & 22,24 \\
& $(0,13)(\mathrm{a})$ & $(0,22)(\mathrm{b})$ & $(0,34)(\mathrm{c})$ \\
\hline Lignin (\%) & 27,31 & 30,54 & 21,66 \\
& $(0,07)(\mathrm{a})$ & $(0,12)(\mathrm{b})$ & $(0,18)(\mathrm{c})$ \\
\hline Ash (\%) & 0,34 & 0,49 & 0,22 \\
& $(0,02)(\mathrm{a})$ & $(0,05)(\mathrm{b})$ & $(0,04)(\mathrm{c})$ \\
\hline Amount of condensed tannin (\%) & 10,78 & 13,89 & 8,03 \\
& $(0,19)(\mathrm{a})$ & $(0,15)(\mathrm{b})$ & $(0,17)(\mathrm{c})$ \\
\hline
\end{tabular}

Note: Numbers in the parenthesis are standard deviations. Different letters in the same line represent statistical differences at $95 \%$ confidence level. 


\section{Surface properties}

The surface roughness and contact angles of the test panels are presented in Table 4 . The test panels manufactured from sapwood had the smoothest surface $\left(7,49 \mu \mathrm{m}\left(\mathrm{R}_{\mathrm{a}}\right) 48,86 \mu \mathrm{m}\left(\mathrm{R}_{\mathrm{y}}\right)\right.$, and 35,12 $\left.\mu \mathrm{m}\left(\mathrm{R}_{\mathrm{z}}\right)\right)$ and the lowest contact angles $\left(67,8^{\circ}\right)$, while the roughest surface $\left(14,20 \mu \mathrm{m}\left(\mathrm{R}_{\mathrm{a}}\right) 68,05^{\mathrm{y}} \mu \mathrm{m}\left(\mathrm{R}_{\mathrm{y}}\right)\right.$, and $\left.50,02 \mu \mathrm{m}\left(\mathrm{R}_{\mathrm{z}}\right)\right)$ and highest contact angle $\left(96,9^{\circ}\right)$ were obtained from the panels manufactured from heartwood. This may be due to high amount of extractives (Table 2) in the heartwood. Extractives and ash negatively affect the surface quality of particleboard. These affect negatively the bonding of wood. Poor bonding increases the surface roughness of particles (Lehman and Geimer 1974, Muhcu et al. 2015). One of the most important factors affecting the contact angle results is surface roughness. If the contact angle value measured on the surface of the material generally exceeds $80^{\circ}$, the contact angle value increases as the surface roughness increases (Buscher et al. 1984, Onda et al. 1996).

Table 4: Average surface roughness and contact angles.

\begin{tabular}{|c|c|c|c|c|}
\hline Panel Types & $\mathbf{R}_{\mathbf{a}}(\boldsymbol{\mu m})$ & $\mathbf{R}_{\mathbf{y}}(\boldsymbol{\mu m})$ & $\mathbf{R}_{\mathbf{z}}(\boldsymbol{\mu m})$ & $\begin{array}{c}\text { CA } \\
\text { Degree }\left({ }^{\circ}\right) \mathbf{a t} \mathbf{5} \mathbf{~ s}\end{array}$ \\
\hline Hearthwood & 14,20 & 68,05 & 50,02 & 96,9 \\
& $(0,38) \mathrm{a}$ & $(0,79) \mathrm{a}$ & $(0,98) \mathrm{a}$ & $(0,99) \mathrm{a}$ \\
\hline Sapwood & 7,49 & 48,86 & 35,12 & 67,8 \\
& $(0,22) \mathrm{b}$ & $(0,59) \mathrm{b}$ & $(0,77) \mathrm{b}$ & $(1,30) \mathrm{b}$ \\
\hline Total wood & 10,88 & 54,98 & 40,81 & 82,9 \\
& $(0,23) \mathrm{c}$ & $(0,69) \mathrm{c}$ & $(0,79) \mathrm{c}$ & $(1,32) \mathrm{c}$ \\
\hline
\end{tabular}

Note: Numbers in the parenthesis are standard deviations. Different letters in the same column represent statistical differences at 95\% confidence level.

\section{Physical and mechanical properties and formaldehyde emission}

5.

The physical and mechanical properties and formaldehyde content of particleboards are presented in Table

Table 5: Mechanical properties, water resistance, and formaldehyde content of test panels.

\begin{tabular}{|c|c|c|c|c|c|}
\hline $\begin{array}{c}\text { Panel } \\
\text { Types }\end{array}$ & $\begin{array}{c}\text { MOR } \\
\text { (MPa) }\end{array}$ & $\begin{array}{c}\text { MOE } \\
\text { (MPa) }\end{array}$ & $\begin{array}{c}\text { IB } \\
(\mathbf{M P a})\end{array}$ & $\begin{array}{c}\text { TS } \\
(\mathbf{\%})\end{array}$ & $\begin{array}{c}\text { FE } \\
(\mathbf{m g} \\
\left.\mathbf{C H}_{\mathbf{2}} \mathbf{O}\right)\end{array}$ \\
\hline Hearthwood & 10,10 & 1369 & 0,225 & 19,88 & 7,28 \\
& $(0,38) \mathrm{a}$ & $(98) \mathrm{a}$ & $(0,030) \mathrm{a}$ & $(0,23) \mathrm{a}$ & $(0,02) \mathrm{a}$ \\
\hline Sapwood & 15,60 & 2201 & 0,523 & 33,85 & 9,05 \\
& $(0,43) \mathrm{b}$ & $(61) \mathrm{b}$ & $(0,019) \mathrm{b}$ & $(0,29) \mathrm{b}$ & $(0,06) \mathrm{b}$ \\
\hline Total wood & 12,74 & 1723 & 0,329 & 26,77 & 8,51 \\
& $(0,25) \mathrm{c}$ & $(85) \mathrm{c}$ & $(0,013) \mathrm{c}$ & $(0,48) \mathrm{c}$ & $(0,03) \mathrm{c}$ \\
\hline
\end{tabular}

Note: Numbers in the parenthesis are standard deviations. Different letters in the same column represent statistical differences at 95\% confidence level. 
The 12,5 MPa and $13 \mathrm{MPa}$ are the minimum requirements of MOR of particleboard for general usage and interior fitments (including furniture), respectively, while the minimum MOE for interior fitment is $1800 \mathrm{MPa}$, based on EN 312 (2005) standard. The minimal requirements of IB strength for general purpose and furniture manufacturing are $0,28 \mathrm{MPa}$ and $0,40 \mathrm{MPa}$, respectively. The panels made from sapwood had the required levels of MOR, MOE and IB for general purposes and furniture manufacturing. The particleboards made from total wood met the required levels of MOR, MOE and IB only for general purposes. Panels made from heartwood did not have the required levels of mechanical strength properties. According to the test results, the test panels did not have the required level of TS property according to EN 312 (2005) standard due to no usage of water-repellent agents, such as paraffin, in the manufacturing process. The maximum permissible formaldehyde content for $\mathrm{E}_{1}$ quality particleboard is $8 \mathrm{mg} \mathrm{CH}_{2} \mathrm{O} / 100 \mathrm{~g}$ dry particleboard sample (EN 120-1 1994). The panels made from heartwood met the required level of $\mathrm{FE}$ for $\mathrm{E}_{1}$ quality.

The thickness swelling and formaldehyde emission values of the panels manufactured from heartwood are significantly lower than the panels manufactured from the total wood and sapwood. The highest mechanical strength values (modulus of rupture, modulus of elasticity and internal bond strength) were obtained from sapwood, followed by total wood, and the heartwood, respectively. Density of the heartwood is higher than that of sapwood. When the wood at high density is chipped, the particles are rough and thick. Rough and thick particles absorb the adhesive. Therefore, there is not enough adhesive on the particle surfaces. So that the mechanical strength properties decrease (Lyman 1969). The $\mathrm{pH}$ of the extract should be 4-5 for good adhesion and blending operation. The $\mathrm{pH}$ of extract of the heartwood was found as 3,03 (Table 3). Low $\mathrm{pH}$ of the extract causes precuring of adhesive before hot pressing application, and decreases the strength properties (Maloney 1977). The skeleton of the wood is cellulose. Cellulose and lignin are wood components that give strength to the wood (Baharoglu et al. 2013). In this study, sapwood had higher amounts of cellulose. For these reasons, panels from sapwood had higher mechanical strength properties.

The water is connected to the $\mathrm{OH}$ groups of cellulose and hemicellulose (Baharoglu et al. 2013). Heartwood had higher lignin and amount of condensed tannin. Lignin and consended tannin have hydrophobe structure. However, hemicellulose has hydrophilic structure. Hemicelluloses absorb a greater amount of water than cellulose. (Sari et al. 2012). Particleboards made from sapwood and total wood had higher thickness swelling values due to a higher amount of hemicelluloses. The adhesive has to wet, flow and penetrate the cellular structure of wood in order to establish intimate contact between molecules of wood and adhesive. Heartwood had higher amounts of extractives than those of total wood and sapwood. The extractives, such as wax, phenolic compounds, liphophilic, and condensed tannin, positively affect the dimensional stability and formaldehyde emission. Tannin and phenolic extractives fix the formaldehyde as a formaldehyde scavenger. (Akbulut 1995). For these reasons, the usage of heartwood reduces the amount of thickness swelling and formaldehyde content. The positive effects of these extractives on the resistance to water (Marshall et al. 1974, Sari et al. 2012) and formaldehyde emission (Sari et al. 2012) were mentioned in a previous work.

High amount of extractives decreases the wettability of wood particles. Extractives cause poorer mechanical properties due to breaking down the adhesive linkage. They negatively affect adhesive bonding and adhesion. Decreasing contact angle and roughness increase the adhesion and wettability of the wood particles. The panels from sapwood had smoother surfaces and lower contact angle (Table 4). Increasing adhesion causes high adhesive bonds and mechanical properties. Some extractives are translated to the wood surfaces by the water during the drying and pressing processes. When the water is vaporized, these extractives stayed in solid form on the particle surfaces. This condition negatively affects quality of gluing and adhesion (Wasniewski 1989, Christiansen 1990, Ayrilmis and Winandy 2009, Huang et al. 2011). The ash content of heartwood is significantly higher than those of sapwood and total wood (Table 3). The ash has lower wettability than the wood, which decreases the bond quality. A non-polar surface of the ash makes it hard for the water-based adhesive to wet and penetrates into the cellular structure, resulting in the poor adhesion between the resin and wood (Muhcu et al. 2015). This is the other reason for the lower strength properties of the particleboards manufactured from heartwood. In a previous study (Pan et al. 2007), MOR, MOE and IB of the particleboard manufactured from saline eucalyptus heartwood were found to be 13,6 MPa; 1564,2 MPa and 1,31 MPa, respectively. 2 hours and 24 hours thickness of physical properties were $31,26 \%$ and $38,28 \%$, respectively. In the same study, the thickness swelling from 2 hours and 24 hours were found to be 31,26 and 38,28\%, respectively. In another study (Duchesne et al. 2016), it was found that heartwood proportion did not have any significant effect on MOE and MOR. In a 1994 study, it was found that particleboards made of sapwood especially had a higher bending strength (Roffael and Dix 1994). 


\section{CONCLUSIONS}

In this work, it is aimed to understand the effect of sapwood and heartwood usage on the quality features of particleboards. Thickness swelling, mechanical and surface properties, wettability, and formaldehyde emission of particleboards were significantly affected by the usage of sapwood and heartwood. Nowadays, there is a shortage of raw materials in particleboard production. The results revealed that European Larch trees can be used to produce particleboards in the case of the addition of water-repellent agent. The best mechanical strength, surface smoothness and wettability values were obtained from the particleboards manufactured from sapwood. The thickness swelling and formaldehyde emission of particleboards manufactured from heartwood were significantly lower than those of total wood and sapwood. Particleboards are generally evaluated in general use and furniture production. When we consider the mechanical properties of the work we have done, it is determined that the particleboards made from sapwood are suitable for furniture and general use, but the particleboards made from heartwood do not fit into any use. Therefore, it may not be appropriate to use the heartwood alone.

\section{REFERENCES}

Akbulut, T. 1995. Effects of various factors on the properties of particleboard, Ph.D. Thesis, Istanbul University, Faculty of Forestry, Istanbul, Turkey. <https://tez.yok.gov.tr/UlusalTezMerkezi/tezSorguSonucYeni. jsp>. (Access 07/06/2017).

Akyuz, K.C.; Nemli, G.; Baharoglu, M.; Zekovic, E. 2010. Effects of acidity of the particles and amount of hardener on the physical and mechanical properties of particleboard composite bonded with urea formaldehyde. Journal of Adhesion and Adhesives 30(3): 166-169.

Atac, Y. 2009. Examination some softwood and hardwood trees interms of paper properties of their sapwood and hearthwood. Ph.D. Thesis, Bartin University, Bartin, Turkey. <https://tez.yok.gov.tr/UlusalTezMerkezi/ tezSorguSonucYeni.jsp>. (Access 07/06/2017).

Atar, I.; Nemli, G.; Ayrilmis, N.; Baharoglu, M.; Sari, B.; Bardak, S. 2014. Effects of hardener type, urea usage and conditioning period on the quality properties of particleboard. Materials and Design 56: 91-96.

Ayrilmis, N.; Buyuksari, U.; Avci, E.; Koc, E. 2009. Utilization of pine cone in manufacture of wood based composite. Forest Ecology Management 259(1): 65-70.

Ayrilmis, N.; Winandy, J.E. 2009. Effect of post heat treatment on surface characteristics and adhesive bonding performance of MDF. Materials and Manufacturing Processes 24 (5): 594-599.

Baharoglu, M.; Nemli G.; Sari, B.; Bardak, S.; Ayrilmis, N. 2012. The influence of moisture content of raw material on the physical and mechanical properties, surface roughness, wettability and formaldehyde emission of particleboard composite. Composites Part B: Engineering 43(5): 2448-2451.

Baharoglu, M.; Nemli, G.; Sari, B.; Birturk, T.; Bardak, S. 2013. Effects of anatomical and chemical properties of wood on the qualityof particleboard. Composites: Part B Engineering 52: 282-285.

Baharoglu, M.; Nemli, G.; Sari, B.; Ayrilmis, N.; Bardak, S.; Zekovic, E. 2014. Effect of paraffin application technique on the physical and mechanical properties of particleboard. Science and Engineering of Composite Materials 21(2): 191-195.

Blanchet, P.; Cloutier, A.; Riedl, B. 2000. Particleboard produced from hammer milled black spruce bark residues. Wood Science and Technology 34(1): 11-19.

Bardak, S. 2014. Usability possibilities of wood of tree of heaven (Ailanthus altissima (Mill.) Swingle) in particleboard industry, Ph.D. Thesis, Karadeniz Technical University, Faculty of Forestry, Trabzon, Turkey. $<$ https://tez.yok.gov.tr/UlusalTezMerkezi/tezSorguSonucYeni.jsp>. (Access 07/06/2017). 
Bardak, S.; Sari B.; Nemli, G.; Kirci, H.; Baharoglu, M. 2011. The effect of decor paper properties and adhesive type on some properties of particleboard. International Journal of Adhesion and Adhesives 31(6): 412-415.

Bardak, S.; Nemli, G.; Tiryaki, S. 2017. The influence of raw material growth region, anatomical structure and chemical composition of wood on the quality properties of particleboards. Maderas- Cienc Tecnol 19(3): 363-372.

Buscher, H.J.; Pelt, A.W.J.; Boer, P.; Arends, J. 1984. The effect of surface roughening of polymers on measured contact angles of liquids. Colloids and Surfaces 9(4): 319-331.

Campbell, A.G.; Kim, W.J.; Koch, P. 1990. Chemical variation in lodgepole pine with sapwood/heartwood, stem height, and variety. Wood and Fiber Science 22(1): 22-30.

Christiansen, A.W. 1990. How over drying wood reduces its bonding to phenol formaldehyde adhesives: A critical review of the literature, Part 1: the physical responses. Wood and Fiber Science 22(4): 441-459.

Duchesne, I.; Vincent, M.; Wang, X.A.; Ung, C.H.; Swift, D.E. 2016. Wood mechanical properties and discoloured heartwood proportion in sugar maple and yellow birch grown in New Brunswick. BioResources 11(1): 2007-2019.

European Committe for Standardization. EN. 1994. Determination of formaldehyde content in fiberboard by using perforator method. EN 120-1. 1994. Brussels.

European Committe for Standardization. EN. 1993. Wood based panels, determination of modulus of elasticity in bending and bending strength. EN 310. 1993. Brussels.

European Committe for Standardization. EN. 2005. Particleboards-specifications. EN 312. 2005. Brussels-Belgium.

European Committe for Standardization. EN. 1993. Particleboard and fiberboards, determination of swelling in thickness after immersion in water. EN 317. 1993. Brussels.

European Committe for Standardization. EN. 1993. Particleboard and fiberboards, determination of tensile strength perpendicular to the plane of the board. EN 319. 1993. Brussels.

Foster W.G. 1967. Species variation. In: Maloney T, editor. Proceedings of the WSU Particleboard Symposium, Volume 1, Pullmann (WA): Washington State University, p. 13-20.

Garay, R.M.; MacDonald, F.; Acevedo, M.L.; Calderón, B.; Araya, J.E. 2009. Particleboard made with crop residues mixed with wood from Pinus radiata. BioResources 4(4): 1396-1408.

Huang, H.; Wang, B.J.; Dong, L.; Zhao, M. 2011. Wettability of hybrid poplar veneers with cold plasma treatments in relation to drying conditions. Drying Technology 29(3): 323-330.

ISO 4287. 1997. International standard geometrical products specifications (GPS) surface texture: profile method terms, definitions, and surface texture parameters. ISO 4287. Geneva.

Kord, B.; Zare, H.; Hosseinzadeh, A. 2016. Evaluation of the mechanical and physical properties of particleboard manufactured from Canola (Brassica napus) straws. Maderas-Cienc Tecnol 18(1): 9-18.

Lehman, W.F.; Geimer, R.L. 1974. Properties of structural particleboards from douglas-fir forest residues. Forest Products Journal 24(10): 17-25.

Lyman, F.C. 1969. Factors influencing the properties of wood chipboard. In: Mitlin, L. editor. Particleboard manufacture and application. London: Presmedia Books; p. 145-149. <https://www.amazon.co.uk/PARTICLEBOARD-MANUFACTURE-APPLICATION-Editor-Mitlin/dp/B000XXZKXQ $>$. (Access 08/06/2017).

Maloney, T.M. 1977 Modern particleboard and dry process fiberboard manufacturing. San Francisco (CA): Miller Freeman. < https://www.amazon.com/Modern-Particleboard-Dry-Process-Fiberboard-Manufacturing/dp/0879305290>. (Access 08/06/2017). 
Marshall, S.W.; Ifju, G.; Johnson, J.A. 1974. The role of extractives in the hydrophobic behavior of lobly pine rhytidome. Wood Fiber Sci 5(4): 353-363.

Motted, A.L. 1967. The particle geometry factor. In: Maloney T, editor. Proceedings of the WSU Particleboard Symposium, Volume 1, Pullmann (WA): Washington State University, p. 23-73.

Moubarik, A.; Mansouri, H.R.; Pizzi, A.; Charrier, F.; Allal, A. 2013. Bertrand charrier corn flour-mimosa tanin-based adhesives without formaldehyde for interior particleboard Production. Wood Science and Technology 47(4): 675-683.

Muhcu, S.; Nemli, G.; Ayrilmis, N.; Bardak, S.; Baharoglu, M.; Sari, B.; Gercek, Z. 2015. Effect of log position in European Larch (Larix decidua Mill.) tree on the technological properties of particleboard. Scandinavian Journal of Forest Research 30(4): 357-362.

Nazerian, M.; Beyki, Z.; Gargarii, R.M.; Kool, F. 2016. The effect of some technological production variables on mechanical and physical properties of particleboard manufactured from cotton (Gossypium hirsutum) stalks. Maderas-Cienc Tecnol 18(1): 167-178.

Nemli, G.; Demirel, S. 2007. Relationship between the density profile and the technological properties of the particleboard composite. Journal of Composite Materials 41(15): 1793-1802.

Nemli, G.; Ozturk, I. 2006. Influences of Some Factors on the Formaldehyde Content of Particleboard. Building and Environment 41(6): 770-774.

Nemli, G.; Yildiz, S.; Gezer, E.D. 2008. The potential for using the needle litter of Scotch pine as a raw material for particleboard manufacturing. Bioresource Technology 99(14): 6054-6058.

Onda, T.; Shibuichi, S.; Satoh, N.; Tsujii, K. 1996. Super-water-repellent fractal surfaces. Langmuir 12(9): 2125-2127.

Ors, Y.; Keskin, H. 2001. Wood material information. Atlas: İstanbul, Turkey. $<$ https://www.kitapyurdu. com/kitap/agac-malzeme-bilgisi/73127.html >. (Access 09/06/2017).

Pan, Z.; Zheng, Y.; Ruihong, Z.; Jenkins, B.M. 2007. Physical properties of thin particleboard made from saline eucalyptus. Industrial Crops and Products 26(2): 185-194.

Prasetya, B. 1989. The investigations on the barks of various tree species. Bachelor thesis on the afforestation of tropic and subtropic regions. Gottingen: Forestry faculty, Universityof Gotingen Georg-August University of Gottingen. <https://www.unigoettingen.de/en/master+thesis+topics+offers/72805.html > . (Access 09/06/2017).

Roffael, E.; Dix, B. 1994. Influence of the wood properties of some poplar clones on utilization. Forstarchiv 65(2): 43-53.

Sari, B.; Ayrilmis, N.; Nemli, G.; Baharoglu, M.; Esat, G.; Bardak, S. 2012. Effects of chemical composition of wood and resin type on properties of particleboard. Lignocellulose 1(3): 174-184.

Sari, B.; Nemli, G.; Baharoglu, M.; Bardak, S.; Zekovic, E. 2013. The role of solid content of adhesive and panel density on the dimensional stability and mechanical properties of particleboard. Journal of Composite Materials 47(10): 1247-1255.

Sivrikaya, H. 2008. Factors effecting natural durability in wood. Journal of Bartin Faculty of Forestry 10(13): 66-70.

TAPPI. 1992. Sampling ad preparing wood for analysis. TAPPI T 11 M-45. 1992. TAPPI test methods. Atlanta (GA): TAPPI Press.

TAPPI. 1997. Solvent extractives of wood and pulp. T $204 \mathrm{~cm}-97.1997$. TAPPI test methods. Atlanta (GA): TAPPI Press.

TAPPI. 1988. Water solubility of woodand pulp. TAPPI T 207 om-88. 1988. TAPPI test methods, Atlanta 
(GA): TAPPI Press.

TAPPI. 1993. Ash in wood, pulp, paperand paperboard. T 211 om-93.1993. TAPPI test methods. Atlanta (GA): TAPPI Press.

TAPPI. 1998. One percent sodiumhydroxide solubility of wood and wood pulp. T 212 om-98. 1998. TAPPI testmethods. Atlanta (GA): TAPPI Press.

TAPPI. 2002. Acid-insoluble lignin inwood and pulp. T $222 \mathrm{om}-02$. 2002. TAPPI test methods. Atlanta (GA): TAPPI Press.

Tisler, V.; Galla, E.; Pulkinen, E. 1986. Fractination of hot water extract from Picea abies Karst. bark. Holz als Roh- und Werkstoff 44(11): 427-431.

Wasniewski, J.L. 1989. Evaluation of juvenile wood and its effect on Douglas-fir structural composite panels. In: Proceedings of the 23 rd Washington State University International Particleboard, Washington, DC.

Wise, E.L.; Karz, H.L. 1962. Cellulose and hemicelluloses. In: Earl Libby, C. editor. Pulp and paper science and technology. New York: McGray Book Com, p. 55-73. < https://www.worldcat.org/title/ pulp-and-paper-science-and-technology/oclc/568013585>. (Access 05/06/2017). 